\title{
Acceptance of ambivalent sexism in trainee teachers in Spain and Latin American countries
}

\author{
Enrique Bonilla-Algovia*
}

Universidad de Alcalá (Spain).

\begin{abstract}
Título: Aceptación del sexismo ambivalente en docentes en formación de España y países de América Latina.

Resumen: El sexismo ambivalente es un constructo multidimensiona compuesto por dos componentes: el sexismo hostil y el sexismo benévolo. El objetivo de este estudio ha sido analizar la aceptación de las actitudes sexistas ambivalentes en una muestra de futuros y futuras docentes de España y Latinoamérica. La investigación está basada en una estrategia metodológica cuantitativa. Participaron 2798 docentes en formación con una edad media de 22.62 años $(D T=6.23)$ que residían en siete países: España El Salvador, Nicaragua, Colombia, Chile, Argentina y México. La técnica de recogida de datos fue el cuestionario estructurado. Los resultados muestran que las actitudes sexistas están presentes, con diferentes grados de aceptación, en el profesorado en formación de todos los países. La aceptación del sexismo varía significativamente entre hombres y mujeres y entre los países de la muestra. Parece existir una relación entre los niveles de sexismo y los índices de desigualdad de género y desarrollo humano. Las instituciones educativas no están exentas de obstáculos y sesgos de género que impiden la consecución de la igualdad entre mujeres y hombres. Las actitudes sexistas del profesorado pueden transmitirse a través del sistema educativo y los procesos de socialización, por lo que es fundamental incluir la perspectiva de género en los planes de formación inicial y continua del profesorado.

Palabras clave: Actitudes. Sexismo ambivalente. Sexismo hostil. Sexismo benévolo. Formación inicial del profesorado. Programas de Formación docente.
\end{abstract}

\section{Introduction}

Sexism operates as an ideology and encompasses a series of attitudes addressed to people according to their sex. Ever since the first studies were conducted in the 1950s, sexism has been recognised as one of the main causes of social inequality worldwide (Boira et al., 2017) and the result of beliefs about the roles and norms assigned to men and women (Gonçalves et al., 2015). That is, sexism describes and prescribes the behaviours that are considered appropriate for men and women, and so it establishes how men and women should interact with each other (Carretero \& Nolasco, 2019; Rebollo et al., 2011a). The first theoretical models focused on the more visible and hostile prejudices directed against women, but subsequently, other theoretical models have begun to emerge that simultaneously encompass traditional hostile beliefs and more recent, subtler attitudes (López-Sáez et al., 2019). These theories reveal that new forms of sexism have emerged which although less blatant or visible, continue to perpetuate structural inequalities between men and

* Correspondence address [Dirección para correspondencia]: Enrique Bonilla-Algovia. Aulario María de Guzmán, Calle San Cirilo s/n, 28801, Alcalá de Henares (Spain). E-mail: enrique.bonilla@uah.es (Article received: 02-09-2020, revised: 31-10-2020, accepted: 12-11-2020)
Abstract: Ambivalent sexism is a multidimensional construct composed of two elements: hostile sexism and benevolent sexism. The main aim of this study is to analyse the acceptance of ambivalent sexist attitudes in a sample of future teachers from Spain and Latin America. The research is based on a quantitative methodological strategy. The sample is composed of 2798 trainee teachers, and their mean age is 22.62 years $(S D=6.23)$, they were residing in seven countries: Spain, El Salvador, Nicaragua, Colombia, Chile, Argentina and Mexico. The data collection technique was the structured questionnaire. The results show that ambivalent sexist attitudes exist -to a varying degree- in future teachers of every country. The assumption of sexism varies significantly between men and women and among countries. There seems to be a relationship between levels of sexism with indices of gender inequality and human development. Education institutions are not exempt from obstacles and gender bias that impede the attainment of equality between women and men. Sexist attitudes of teachers can be transmitted through the education system and the socialization process, so including gender issues in initial and in-service teacher training plans is essential.

Keywords: Attitudes. Ambivalent sexism. Hostile sexism. Benevolent sexism. Initial teacher training. Teacher education programs.

women in tandem with more traditional forms of sexism (Bonilla-Algovia \& Rivas-Rivero, 2020).

According to the Ambivalent Sexism Theory, sexism is a multidimensional construct composed of hostile and benevolent attitudes (Glick \& Fiske, 1996, 2011). Ambivalent sexism has its roots in the structural control exerted over women and refers to attitudes relative to three areas: power, gender differentiation and heterosexuality (Glick \& Fiske, 1996; Glick et al., 2000; Lee et al., 2010a). Sexist ambivalence arises from the coexistence of two ideologies (hostile sexism and benevolent sexism) that imply subjectively opposite evaluations of women (Glick \& Fiske, 1996, 2011). In other words, although hostile sexism and benevolent sexism possess a subjectively opposite affective tone (negative and positive, respectively), they are not mutually exclusive but instead complement and reinforce one another. Benevolent sexism acts as a reward for women who behave in accordance with traditional gender roles, while hostile sexism acts as a punishment for those who do not (Glick et al., 2000; Glick \& Fiske, 2011). Consequently, these two types of sexism operate in tandem to perpetuate gender relations and legitimise the inequalities inherent to the patriarchal system (BonillaAlgovia \& Rivas-Rivero, 2020; Lee et al., 2010b).

There is consensus in the literature that the education system, as a space for socialisation, and teachers, as the agents of socialisation, play a major role in mitigating sexism, 
gender stereotypes and inequality between men and women (Azorín, 2017; Bonilla-Algovia \& Rivas-Rivero, 2018; Fabes et al., 2018; Pinedo et al., 2018; Sáez-Rosenkranz et al., 2019); however, as research in different countries has shown, education institutions are not exempt from gender bias or obstacles that impede the attainment of equality (Biemmi, 2015; Brundrett \& Dung, 2018; Gray \& Leith, 2004; Mai \& Brundrett, 2019; Sáenz del Castillo et al., 2019; Sánchez, 2002). The sexist attitudes of education agents can be one of the main barriers for the development of a feminist and egalitarian school (Bonilla-Algovia \& Rivas-Rivero, 2019; Carretero \& Nolasco, 2019; Cordón et al., 2019). Throughout their lives, teachers adopt some beliefs that may interfere with their behaviour in the classroom and with their relationship with students (Sales-Oliveira et al., 2016), so that stereotypical gender beliefs can influence teachers' perceptions, discourses and educational practices (Matheis et al., 2020).

The education system is not a neutral space for socialisation but instead forms part of a larger system. Thus, not only does it reflect prevailing social and cultural norms, but it also reproduces them more or less explicitly in the official curriculum, and above all in the hidden curriculum. This latter consists of the unofficial, non-explicit and unintended lessons (beliefs, attitudes, skills, discourses and meanings) that the education system transmits, whether in the teachinglearning process or in the relations and policies of the educational context (Maceira, 2005). Teachers transmit expectations and values that influence the social construction of gender and form part of this hidden curriculum (BonillaAlgovia \& Rivas-Rivero, 2018; Díaz \& Anguita, 2017; Pinedo et al. 2018).

Studies conducted in various countries have shown that in-service and trainee teachers hold gender stereotypes and sexist beliefs, are resistant to educational change and/or present deficits in their training (Bonilla-Algovia \& RivasRivero, 2019; Carretero \& Nolasco, 2019; Cordón et al., 2019; Díaz \& Anguita, 2017; Gullberg et al., 2018; Rebollo et al., 2011b; Sales-Oliveira et al., 2016), which shows the need and importance of incorporating gender issues in teacher training (Biemmi, 2015; Cushman, 2012; Gray \& Leith, 2004; Rebollo et al., 2011a; Sáez-Rosenkranz et al., 2019; Sáenz del Castillo et al., 2019). Consequently, since education is one of the most suitable spaces to fight sexism and develop a fairer society, the analysis of the sexist attitudes of future teachers implies an examination of one of the hidden elements that can be conveyed in educational interactions but which do not form part of the official curriculum.

Furthermore, in recent decades, cross-cultural research conducted in different regions has shown that sexism towards women persists in most societies and cultures (Brandt, 2011; Glick et al., 2000, 2004; Napier et al., 2010). One study with approximately 15,000 participants from 19 countries (including Chile, Colombia and Spain) confirmed that sexism exists at transcultural level and includes subjectively positive and negative evaluations that correlate with and complement one another (Glick et al., 2000). Men presented higher levels of hostile sexism than women in all countries. However, gender differences in benevolent sexism scores tended to decrease, disappear or even were reversed in some countries. Using the same multi-country sample, Moya et al. (2002) found inverse relationships between levels of hostile and benevolent sexism and national indices of human development, and again provided evidences that women reject hostile sexist attitudes more than men.

Along the same lines, another study with 8360 participants from 16 countries (including Argentina, Colombia, Mexico and Spain) showed that levels of ambivalent sexism vary among countries and found an association between hostile sexism and benevolent sexism with national indices of gender inequality (Glick et al., 2004). The results also showed differences between sexes in the scores for ambivalent sexism. In all countries, men accepted hostile sexism more than women did. By contrast, differences between women and men in benevolent sexism scores varied: in five countries, the highest scores correspond to men; in two countries, the highest scores correspond to women; and in nine countries, there were no significant differences. Similarly, a study with participants from 32 countries (including Chile, Colombia, Mexico, El Salvador and Spain) found a significant effect of gender and country on attitudes toward women, such that the acceptance by men and women of benevolent and hostile attitudes varied significantly across countries (Napier et al., 2010).

To date, as stated above, various cross-cultural studies have been conducted on acceptance of ambivalent sexism using samples drawn from students and/or from the general population (Brandt, 2011; Glick et al., 2000, 2004; Napier et al., 2010); however, the present study is the first to analyse ambivalent sexism in a cross-cultural sample consisting of Spanish-speaking trainee teachers so far. The fact that sexism has been little studied in the field of education raises questions about to what extent future teachers will accept sexist attitudes.

The study objectives were determining levels of ambivalent sexism towards women; analysing differences in means between men and women; comparing the acceptance of sexism across countries; and finally assessing the relationship between levels of sexism with national indices of gender inequality and human development in a sample of trainee teachers in Spain and Latin America. The study hypotheses were as follows: a) sexist attitudes will be present in trainee teachers of every country; b) men will score significantly higher than women in ambivalent sexism and hostile sexism, while in benevolent sexism the differences between sexes will vanish or decrease, c) acceptance of sexism will vary significantly across countries; and d) levels of hostile and benevolent sexism will correlate positively with national indicators of gender inequality and negatively with national indicators of human development. 


\section{Method}

\section{Design}

The study is based on a quantitative methodological strategy. According to this research criterion and considering the sample size and the specificity of the variables, data were collected with a survey. The research design was correlational, and the approach was cross-sectional, since data collection was at a single time point. Specifically, it consisted of a self-administered and structured questionnaire. The methodological design allowed to contrast the hypotheses and analyse the association between the study variables.

\section{Participants}

The study sample consisted of 2798 trainee teachers in Spain and Latin America with a mean age of 22.62 years (SD $=6.23$ ). According to their sex, $76.1 \%$ of the participants are women, $23.8 \%$ are men and $0.1 \%$ are other. The research recruited trainee teachers from more than twenty universities and/or teacher training centres in seven countries: Spain, El Salvador, Nicaragua, Colombia, Chile, Argentina and Mexico. Participants were studying various education and/or teaching degrees, including teacher training in preschool education and primary education, special needs education, childhood education, educational psychology and subject specialisation. The sample was selected by means of nonprobability intentional sampling. The degree courses were different in each of the countries, so researchers established common criteria for inclusion in the sample: a) residing in any of the participant countries; b) enrolled in any public or private university or higher education centre; c) undertaking teacher training for any level of compulsory education (preschool, primary or secondary education); and d) studying for an officially recognised degree that would qualify the holder to work in an educational institution. Table 1 shows the sociodemographic characteristics of the study sample.

Table 1

Sample characteristics.

\begin{tabular}{lcccccc}
\hline & \multicolumn{3}{c}{ All } & Women & \multicolumn{2}{c}{ Men } \\
\cline { 2 - 6 } & $n$ & Mean age $(S D)$ & $n$ & Mean age $(S D)$ & $n$ & Mean age $(S D)$ \\
\hline Spain & 1168 & $20.97(4.46)$ & 949 & $20.72(4.30)$ & 219 & $22.08(4.94)$ \\
El Salvador & 211 & $22.43(4.92)$ & 130 & $22.08(4.63)$ & 81 & $23.00(5.35)$ \\
Nicaragua & 138 & $27.38(8.77)$ & 84 & $29.87(8.83)$ & 54 & $23.50(7.16)$ \\
Colombia & 443 & $20.64(3.91)$ & 317 & $20.62(3.70)$ & 126 & $20.67(4.41)$ \\
Chile & 101 & $21.03(2.11)$ & 61 & $20.80(1.91)$ & 40 & $21.38(2.36)$ \\
Argentina & 467 & $28.12(8.92)$ & 383 & $28.66(8.88)$ & 84 & $25.65(8.76)$ \\
Mexico & 270 & $21.77(3.21)$ & 205 & $21.43(2.66)$ & 63 & $22.87(4.43)$ \\
\hline
\end{tabular}

\section{Measures}

1. Ambivalent Sexism Inventory (ASI, Glick \& Fiske, 1996). The ASI has been cross-culturally validated and measures ambivalent sexism towards women (Glick et al., 2000). For the present study, the short version of the Spanish adaptation (Bonilla-Algovia \& Rivas-Rivero, 2020; Rodríguez et al., 2009) was used. This version was validated in Spain (Rodríguez et al., 2009), Mexico and El Salvador (Bonilla-Algovia \& Rivas-Rivero, 2020). It consists of twelve items and two factors corresponding to hostile sexism (6 items) and benevolent sexism (6 items). Responses use a Likert-type scale where $0=$ strongly disagree and $5=$ strongly agree. The reliability obtained in this study was satisfactory for all countries in both forms of ambivalent sexism: hostile sexism (Spain, $\alpha$ $=.84 ;$ El Salvador, $\alpha=.86$; Nicaragua, $\alpha=.80$; Colombia, $\alpha$ $=.81 ;$ Chile, $\alpha=.86$; Argentina, $\alpha=.81$; Mexico, $\alpha=.84$ ) and benevolent sexism (Spain, $\alpha=.79$; El Salvador, $\alpha=.76$; Nicaragua, $\alpha=.73$; Colombia, $\alpha=.81$; Chile, $\alpha=.76$; Argentina, $\alpha=.81$; Mexico, $\alpha=.80$ ).

2. Gender Inequality Index (UNDP, 2019). Developed by the United Nations Development Programme, the GII measures inequality and gender gaps in three dimensions of human development: reproductive health (measured using the maternal mortality rate and the adolescent fertility rate), empowerment (measured by the percentage of women and men aged 25 or more who have completed at least part of their secondary education, and the share of parliamentary seats held by each sex) and labour market participation (measured by the rate of participation in the workforce among men and women aged 15 years or more). High scores reflect greater gender inequality. The trainee teachers did not complete this measure; instead, researchers used the GII scores published by the UNDP (2019).

3. Human Development Index (UNDP, 2019). HDI is a summary index that measures progress in three key dimensions of human development: long and healthy life (measured by life expectancy at birth), access to knowledge (measured by expected years of schooling and mean years of schooling) and a decent standard of living (measured by the gross national income per capita). High scores reflect greater human development. The trainee teachers did not complete this measure; researchers used the HDI scores published by the UNDP (2019). 


\section{Procedure}

The research team designed a self-report questionnaire based on the study objectives. Firstly, since the main objective was to obtain a sample of future teachers, common sampling criteria were established in all countries. Bearing in mind the sampling criterion, investigators contacted universities, training centres and/or teachers, depending on each place, who then facilitated access to the sample. After informing the students of the study subject and objectives, they gave their informed consent and were administered the questionnaire, which took approximately 40 minutes to complete. Participation was voluntary and data collection was anonymous. The research team ensured data confidentiality at all times.

\section{Analysis}

Statistical analysis of the data was performed using SPSS (IBM SPSS Statistics 22.0). Calculation of descriptive statistics allowed the analysis of sociodemographic data. Acceptance of sexist attitudes was calculated using the mean and standard deviation. The Student's T-test for independent samples permitted the comparison of the differences in means between women and men. Means for hostile sexism and benevolent sexism were compared using the Student's T-test for related samples. Student's T-test was accompanied by effect size (Cohen's d). The differences in means among countries were assessed by ANOVA and MANOVA. Effect size $\left(\eta^{2}\right)$ and Welch's F-test (W-test) accompanied F-test in univariate tests. When the value for F-test was statistically significant, researchers calculated differences in means among countries using Post Hoc multiple comparisons. Based on the ASI scores, two classification trees for trainee teachers were designed. The relationships between levels of sexism with the UNDP indices (gender inequality and human development) were measured using Pearson and Spearman correlations. For a result to be considered statistically significant the researchers adopted a probability of committing a type I error of $p \leq .05$.

\section{Results}

\section{Comparison of scores between women and men}

The ASI has a response range from 0 to 5 , where higher scores indicate a higher level of sexism. After analysing the total scores on the scale, the results reported that women are significantly less ambivalent sexist than men in all countries: Spain $\left(M_{\text {men }}=1.45, S D=.96 ; M_{\text {women }}=.87, S D=.74 ; t=\right.$ $8.27, p<.001 ; d=.73)$, El Salvador $\left(M_{\mathrm{men}}=2.99, S D=.99\right.$; $\left.M_{\text {women }}=2.42, S D=.92 ; t=4.21, p<.001 ; d=.60\right)$, Nicaragua $\left(M_{\text {men }}=3.13, S D=.80 ; M_{\text {women }}=2.67, S D=.93 ; t=\right.$ 2.97, $p<.01 ; d=.53)$, Colombia $\left(M_{\text {men }}=2.06, S D=.86\right.$; $\left.M_{\text {women }}=1.52, S D=.81 ; t=6.31, p<.001 ; d=.66\right)$, Chile $\left(M_{\text {men }}=1.35, S D=.92 ; M_{\text {women }}=.95, S D=.75 ; t=2.37, p\right.$ $<.05 ; d=.48)$, Argentina $\left(M_{\mathrm{men}}=1.37, S D=1.03 ; M_{\text {women }}=\right.$ $1.07, S D=.85 ; t=2.55, p<.05 ; d=.34)$ and Mexico $\left(M_{\text {men }}\right.$ $=1.94, S D=.98 ; M_{\mathrm{women}}=1.48, S D=.93 ; t=3.43, p<$ $.001 ; d=.49)$.

Figure 1 shows the average scores of the trainee teachers in hostile sexism and in benevolent sexism. In all countries, men showed higher levels of acceptance than women in both forms of sexism; however, the differences in means were not statistically significant in all cases. On the one hand, in terms of hostile sexism, men scored significantly higher than women in Spain $\left(M_{\text {men }}=1.51, S D=1.12 ; M_{\text {women }}=.80\right.$, $S D=.82 ; t=8.84, p<.001 ; d=.80)$, El Salvador $\left(M_{\mathrm{men}}=\right.$ $2.79, S D=1.28 ; M_{\text {women }}=1.85, S D=1.21 ; t=5.29, p<$ $.001 ; d=.75)$, Nicaragua $\left(M_{\mathrm{men}}=2.77, S D=1.11 ; M_{\mathrm{women}}=\right.$ $1.87, S D=1.18 ; t=4.42, p<.001 ; d=.78)$, Colombia $\left(M_{\text {men }}\right.$ $=2.48, S D=1.16 ; M_{\text {women }}=1.67, S D=.95 ; t=6.96, p<$ $.001 ; d=.80)$, Chile $\left(M_{\mathrm{men}}=1.42, S D=1.08 ; M_{\mathrm{women}}=.89\right.$, $S D=.81 ; t=2.65, p<.01 ; d=.57)$ and Mexico $\left(M_{\text {men }}=\right.$ 2.12, $S D=1.22 ; M_{\text {women }}=1.53, S D=1.06 ; t=3.67, p<$ $.001 ; d=.53)$, but not in Argentina, where gender difference was not significant $\left(M_{\mathrm{men}}=1.23, S D=1.05 ; M_{\text {women }}=1.04\right.$, $S D=.96 ; t=1.55, p=.122 ; d=.19)$. On the other hand, although men also tended to score higher than women in benevolent sexism, the differences in means were smaller than in hostile sexism in all countries except Argentina. Differences between men and women were statistically significant in Spain $\left(M_{\text {men }}=1.38, S D=1.05 ; M_{\text {women }}=.95, S D=\right.$ $.89 ; t=5.69, p<.001 ; d=.47)$, Colombia $\left(M_{\text {men }}=1.64, S D\right.$ $\left.=1.05 ; M_{\text {women }}=1.36, S D=.99 ; t=2.67, p<.01 ; d=.28\right)$, Argentina $\left(M_{\text {men }}=1.52, S D=1.20 ; M_{\text {women }}=1.09, S D=\right.$ $1.02 ; t=3.04, p<.01 ; d=.41)$ and Mexico $\left(M_{\mathrm{men}}=1.77, S D\right.$ $\left.=1.11 ; M_{\mathrm{women}}=1.42, S D=1.02 ; t=2.33, p<.05 ; d=.34\right)$, but they were not significant in El Salvador $\left(M_{\text {men }}=3.20\right.$, $S D=1.14 ; M_{\text {women }}=2.99, S D=1.16 ; t=1.27, p=.205 ; d=$ $.18)$, Nicaragua $\left(M_{\mathrm{men}}=3.50, S D=.97 ; M_{\mathrm{women}}=3.45, S D=\right.$ $1.13 ; t=.25, p=.800 ; d=.04)$ and Chile $\left(M_{\text {men }}=1.28, S D=\right.$ $\left..95 ; M_{\text {women }}=1.02, S D=.90 ; t=1.43, p=.155 ; d=.29\right)$. 
Figure 1

Differences between men and women in hostile and benevolent sexism.

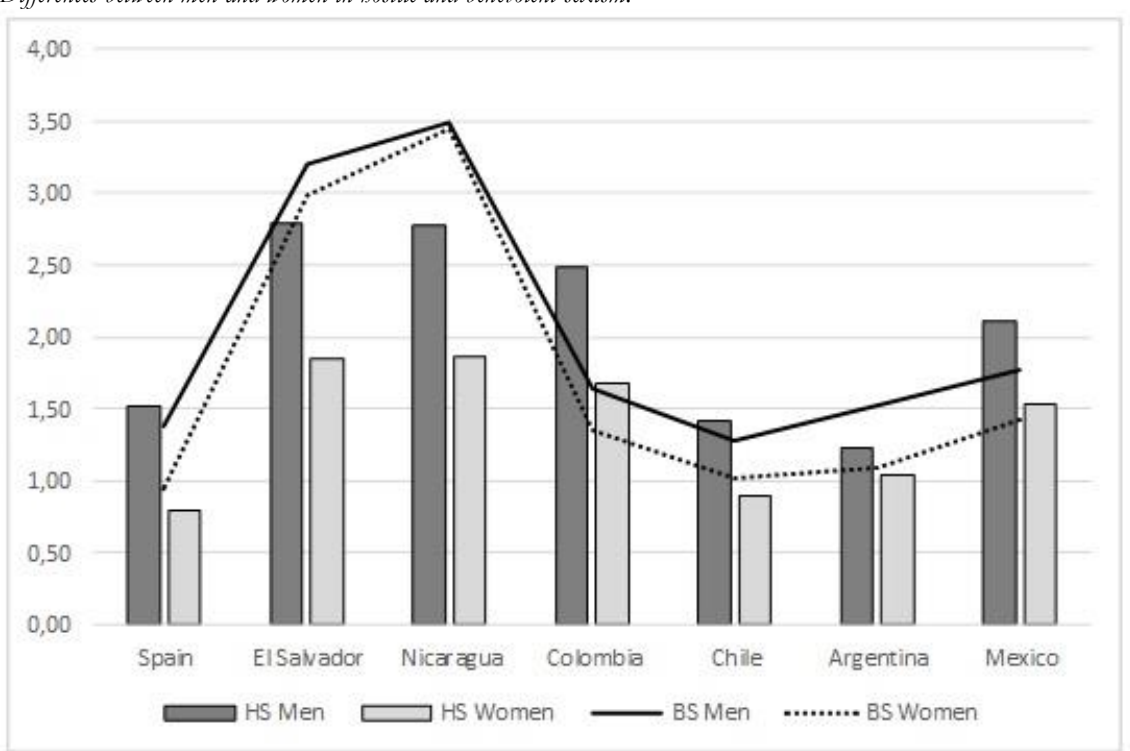

Note: $H S=$ bostile sexism; $B S=$ benevolent sexism.

Table 2 shows the mean differences between hostile sexism and benevolent sexism, using the Student's T test for related samples. On the one hand, women in Spain, El Salvador and Nicaragua accepted benevolent sexism in a higher degree than hostile sexism, while women in Colombia ac- cepted hostile sexism more than benevolent sexism. On the other hand, men from Colombia and Mexico agreed more with hostile sexism than with benevolent sexism, while men from El Salvador, Nicaragua and Argentina agreed with benevolent sexism to a larger extent.

Table 2

Mean differences between bostile sexism and benevolent sexism.

\begin{tabular}{|c|c|c|c|c|c|c|c|c|c|c|c|c|}
\hline \multirow[b]{3}{*}{ Spain } & \multicolumn{6}{|c|}{ Men's average } & \multicolumn{6}{|c|}{ Women's average } \\
\hline & \multirow{2}{*}{$\begin{array}{c}M_{\mathrm{HS}}-M_{\mathrm{BS}} \\
.128\end{array}$} & \multirow{2}{*}{$\begin{array}{c}S D \\
1.01\end{array}$} & \multicolumn{2}{|c|}{ CI 95\% } & \multirow{2}{*}{$\begin{array}{c}\text { T-test } \\
1.89\end{array}$} & \multirow{2}{*}{$\begin{array}{c}d \\
.13\end{array}$} & \multirow{2}{*}{$\begin{array}{c}M_{\mathrm{HS}}-M_{\mathrm{BS}} \\
-.145\end{array}$} & \multirow{2}{*}{$\begin{array}{r}S D \\
.85\end{array}$} & \multicolumn{2}{|c|}{ CI 95\% } & \multirow{2}{*}{$\frac{\text { T-test }}{-5.25^{* * *}}$} & \multirow{2}{*}{$\frac{d}{-.17}$} \\
\hline & & & -.01 & .26 & & & & & -.20 & -.09 & & \\
\hline El Salvador & -.409 & 1.40 & -.72 & -.10 & $-2.61 *$ & -.29 & -1.133 & 1.50 & -1.39 & -.87 & $-8.56^{* * *}$ & -.75 \\
\hline Nicaragua & -.724 & 1.34 & -1.10 & -.35 & $-3.87 * * *$ & -.54 & -1.583 & 1.39 & -1.88 & -1.28 & $-10.45^{* * *}$ & -1.14 \\
\hline Colombia & .840 & 1.39 & .60 & 1.08 & $6.81 * * *$ & .61 & .316 & 1.09 & .20 & .44 & $5.16^{* * *}$ & .29 \\
\hline Chile & .138 & .84 & -.13 & .41 & 1.04 & .16 & -.126 & .81 & -.33 & .08 & -1.21 & -.15 \\
\hline Argentina & -.292 & .95 & -.50 & -.08 & $-2.80 * *$ & -.31 & -.043 & .99 & -.14 & .06 & -.86 & -.04 \\
\hline Mexico & .349 & 1.27 & .03 & .67 & $2.19 *$ & .28 & .117 & .92 & -.01 & .24 & 1.81 & .13 \\
\hline
\end{tabular}

Note: $M_{\mathrm{HS}}-M_{\mathrm{HB}}=$ mean difference; $S D=$ standard deviation; CI $95 \%=$ confidence interval for the mean difference; T-test $=$ paired sample T-test; $d=$ Cohen's $\mathrm{d} ; * p \leq .05 ; * * p \leq .01 ; * * * p \leq .001$

\section{Comparison of scores among countries}

Figure 2 shows the overall levels of ambivalent sexism and its subscales by country. The one-way ANOVA performed to compare mean scores for groups in ambivalent sexism (total score of the ASI scale), where country was the independent variable, revealed statistically significant differences among countries $\left(F=196.39, p<.001, \eta^{2}=.30\right.$; Wtest $=177.99, p<.001):$ Spain $(M=.98, S D=.82)$, El Salvador $(M=2.64, S D=.99)$, Nicaragua $(M=2.84, S D=$
.91), Colombia $(M=1.67, S D=.86)$, Chile $(M=1.11, S D=$ $.84)$, Argentina $(M=1.12, S D=.89)$ and Mexico $(M=1.59$, $S D=.96)$. The between-group sum of squares was 893.07 and the between-group root mean square was 148.84. The total score of the ASI showed that, disaggregating the sample by sex, the differences in means among countries were statistically significant both in the sample of women $(F=134.08$, $p<.001, \eta^{2}=.27$; W-test $\left.=115.25, p<.001\right)$ and in the sample of men $\left(F=47.95, p<.001, \eta^{2}=.30 ; \mathrm{W}\right.$-test $=$ 49.83, $p<.001)$. 
Figure 2

Mean scores for ASI by country.

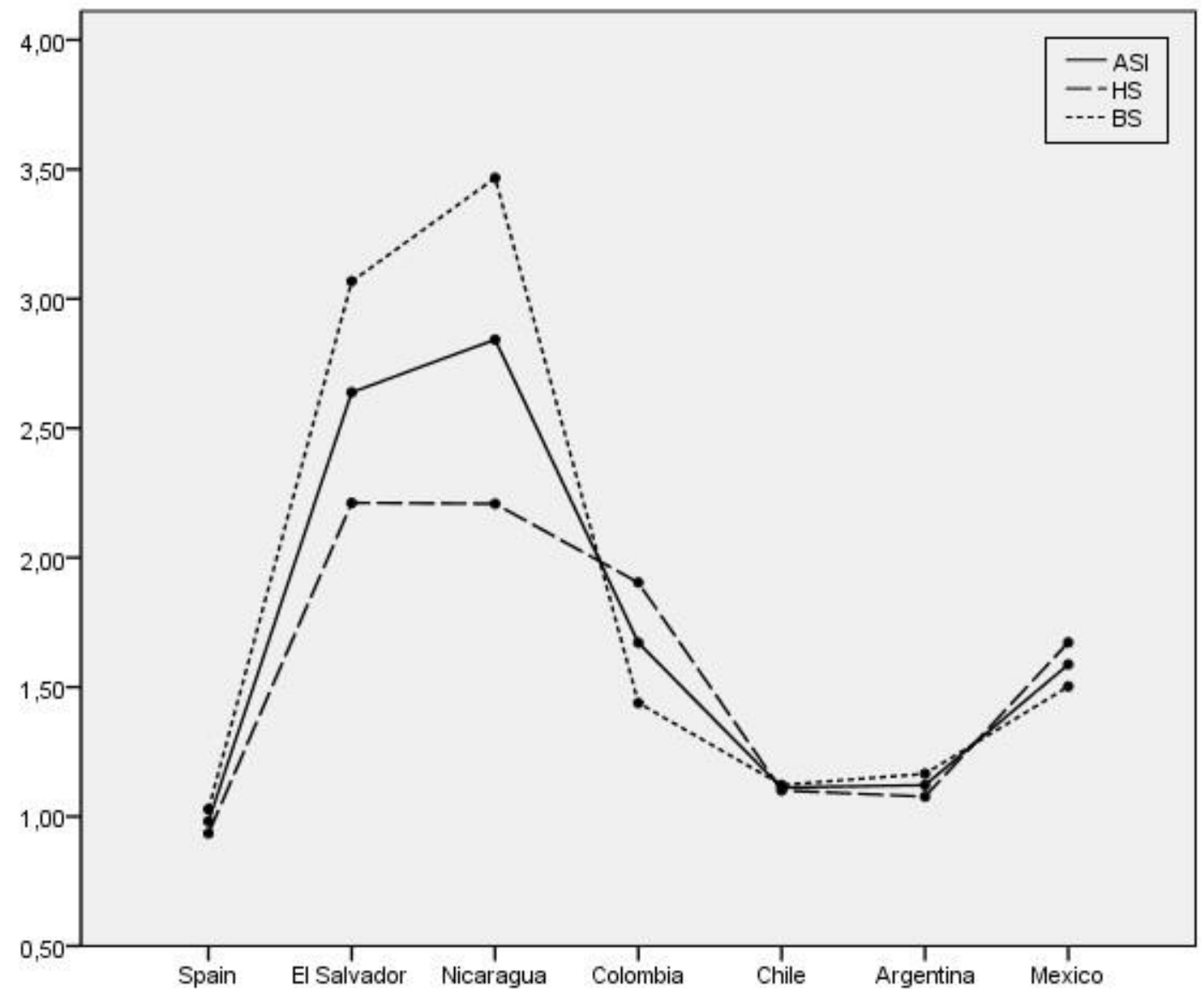

The differences in means among countries for both types of ambivalent sexism (hostile sexism and benevolent sexism) were analysed using a MANOVA, whose results showed the existence of statistically significant differences (Wilks' $\lambda=$ $\left..616, F=127.30, p<.001, \eta^{2}=.22\right)$. Central American countries of Nicaragua and El Salvador obtained the highest scores for hostile sexism, while Spain obtained the lowest $(F$ $=103.87, p<.001, \eta^{2}=.18$; W-test $\left.=90.65, p<.001\right)$. Levels of hostile sexism by country were as follows: Spain $(M=$ .93, $S D=.93)$, El Salvador $(M=2.21, S D=1.32)$, Nicaragua $(M=2.21, S D=1.23)$, Colombia $(M=1.90, S D=$ 1.08), Chile $(M=1.10, S D=.96)$, Argentina $(M=1.08, S D$ $=.98)$ and Mexico $(M=1.67, S D=1.12)$. The betweengroup sum of squares was 661.24 and the between-group root mean square was 110.21 . Similarly, Nicaragua obtained the highest scores for benevolent sexism, while Spain again obtained the lowest $\left(F=223.00, p<.001, \eta^{2}=.32\right.$; W-test $=$ 191.49, $p<.001)$. Levels of benevolent sexism by country were as follows: Spain $(M=1.03, S D=.94)$, El Salvador $(M$ $=3.07, S D=1.16)$, Nicaragua $(M=3.47, S D=1.07)$, Colombia $(M=1.44, S D=1.02)$, Chile $(M=1.12, S D=.92)$, Argentina $(M=1.17, S D=1.06)$ and Mexico $(M=1.50, S D$ $=1.05)$. The between-group sum of squares and the be- tween-group root mean square were 1352.59 and 225.43 , respectively. Therefore, the results of the multivariate and univariate tests showed that for both types of sexism, differences in means between the groups were statistically significant $(p<.001)$, indicating the possible existence of a relationship between these dependent variables (hostile sexism and benevolent sexism) and the independent variable (country).

MANOVA, disaggregating the sample by sex, showed significant differences among countries both in the sample of women (Wilks' $\lambda=.628, F=92.49, p<.001, \eta^{2}=.21$ ) and in the sample of men (Wilks' $\lambda=.598, F=32.01, p<$ $\left..001, \eta^{2}=.23\right)$. In the sample of women, the differences in means among countries were statistically significant for hostile sexism $\left(F=66.55, p<.001, \eta^{2}=.16\right.$; W-test $=60.12, p$ $<.001)$ and benevolent sexism $\left(F=159.54, p<.001, \eta^{2}=\right.$ .31 ; W-test $=121.93, p<.001)$. Same happened with the sample of men, where the differences among countries were significant for hostile sexism $\left(F=28.58, p<.001, \eta^{2}=.21\right.$; W-test $=28.26, p<.001)$ and benevolent sexism $(F=51.74$, $p<.001, \eta^{2}=.32$; W-test $\left.=53.57, p<.001\right)$.

Since statistically significant differences among countries were found for the subscales of ambivalent sexism, a post 
hoc multiple comparison analysis was conducted in order to determine differences between pairs of countries (see Table 3). The results of a comparison of mean scores by pairs of groups confirmed statistically significant differences among countries for the hostile sexism and benevolent sexism.
Women and men from less gender-equal countries, compared to their counterparts from more gender-equal countries, tended to score significantly higher on both forms of sexism.

Table 3

Post hoc analysis of the ASI among countries.

\begin{tabular}{|c|c|c|c|c|c|c|c|c|c|c|c|c|c|}
\hline & $\begin{array}{l}\text { Country } \\
\text { (I) }\end{array}$ & $\begin{array}{c}\text { Country } \\
\left(J_{1}\right)\end{array}$ & $\begin{array}{c}\text { Mean } \\
\text { difference } \\
\left(\mathrm{I}-\mathrm{J}_{1}\right) \\
\end{array}$ & $\begin{array}{c}\text { Country } \\
\left(J_{2}\right)\end{array}$ & $\begin{array}{c}\text { Mean } \\
\text { difference } \\
\left(\mathrm{I}-\mathrm{J}_{2}\right) \\
\end{array}$ & $\begin{array}{c}\text { Country } \\
\left(J_{3}\right)\end{array}$ & $\begin{array}{c}\text { Mean } \\
\text { difference } \\
\left(\mathrm{I}-\mathrm{J}_{3}\right)\end{array}$ & $\begin{array}{c}\text { Country } \\
\left(\mathrm{J}_{4}\right)\end{array}$ & $\begin{array}{c}\text { Mean } \\
\text { difference } \\
\left(\mathrm{I}-\mathrm{J}_{4}\right) \\
\end{array}$ & $\begin{array}{c}\text { Country } \\
\left(J_{5}\right)\end{array}$ & $\begin{array}{c}\text { Mean } \\
\text { difference } \\
\left(\mathrm{I}-\mathrm{J}_{5}\right) \\
\end{array}$ & $\begin{array}{c}\text { Country } \\
\left(J_{6}\right)\end{array}$ & $\begin{array}{c}\text { Mean } \\
\text { difference } \\
\left(\mathrm{I}-\mathrm{J}_{6}\right)\end{array}$ \\
\hline \multirow{8}{*}{ 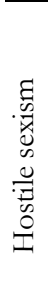 } & \multicolumn{13}{|c|}{ Total sample } \\
\hline & ES & SV & $-1.28 * * *$ & NI & $-1.27 * * *$ & $\mathrm{CO}$ & $-.97 * * *$ & CL & -.17 & AR & -.14 & MX & $-.74 * * *$ \\
\hline & SV & ES & $1.28^{* * *}$ & NI & .00 & $\mathrm{CO}$ & .31 & CL & $1.11^{* * *}$ & $\mathrm{AR}$ & $1.13^{* * *}$ & MX & $.54 * * *$ \\
\hline & NI & ES & $1.27 * * *$ & SV & -.00 & $\mathrm{CO}$ & .30 & CL & $1.11^{* * *}$ & $\mathrm{AR}$ & $1.13^{* * *}$ & MX & $.54 * * *$ \\
\hline & $\mathrm{CO}$ & ES & $.97 * * *$ & SV & -.31 & NI & -.30 & CL & $.80^{* * *}$ & AR & $.83 * * *$ & MX & .23 \\
\hline & CL & ES & .17 & SV & $-1.11 * * *$ & NI & $-1.11 * * *$ & $\mathrm{CO}$ & $-.80^{* * *}$ & AR & .02 & MX & $-.57 * * *$ \\
\hline & AR & ES & .14 & SV & $-1.13^{* * *}$ & NI & $-1.13 * * *$ & $\mathrm{CO}$ & $-.83^{* * *}$ & CL & -.02 & MX & $-.60^{* * *}$ \\
\hline & MX & ES & $.74 * * *$ & SV & $-.54 * * *$ & NI & $-.54 * * *$ & $\mathrm{CO}$ & -.23 & $\mathrm{CL}$ & $.57 * * *$ & AR & $.60^{* * *}$ \\
\hline \multicolumn{14}{|c|}{ Sample of women } \\
\hline \multirow{7}{*}{ 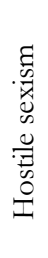 } & ES & SV & $-1.05^{* * *}$ & NI & $-1.06^{* * *}$ & $\mathrm{CO}$ & $-.87 * * *$ & CL & -.09 & AR & $-.24 * * *$ & MX & $-.73^{* * *}$ \\
\hline & SV & ES & $1.05^{* * *}$ & $\mathrm{NI}$ & -.01 & $\mathrm{CO}$ & .18 & $\mathrm{CL}$ & $.96^{* * *}$ & $\mathrm{AR}$ & $.81 * * *$ & MX & .32 \\
\hline & $\mathrm{NI}$ & ES & $1.06^{* * *}$ & SV & .01 & $\mathrm{CO}$ & .19 & $\mathrm{CL}$ & $.98^{* * *}$ & AR & $.82^{* * *}$ & MX & .33 \\
\hline & $\mathrm{CO}$ & ES & $.87 * * *$ & SV & -.18 & NI & -.19 & $\mathrm{CL}$ & $.78^{* * *}$ & AR & $.63 * * *$ & MX & .14 \\
\hline & CL & ES & .09 & SV & $-.96 * * *$ & NI & $-.98 * * *$ & $\mathrm{CO}$ & $-.78 * * *$ & $\mathrm{AR}$ & -.15 & MX & $-.64 * * *$ \\
\hline & AR & ES & $.24 * * *$ & SV & $-.81 * * *$ & NI & $-.82 * * *$ & $\mathrm{CO}$ & $-.63^{* * *}$ & CL & .15 & MX & $-.49 * * *$ \\
\hline & MX & ES & $.73^{* * * *}$ & SV & -.32 & NI & -.33 & $\mathrm{CO}$ & -.14 & CL & $.64 * * *$ & $\mathrm{AR}$ & $.49^{* * *}$ \\
\hline \multirow{8}{*}{ 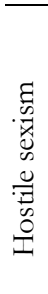 } & \multicolumn{13}{|c|}{ Sample of men } \\
\hline & ES & SV & $-1.28^{* * *}$ & NI & $-1.26^{* * *}$ & $\mathrm{CO}$ & $-.97 * * *$ & CL & .09 & $\mathrm{AR}$ & .28 & MX & $-.61 * *$ \\
\hline & SV & ES & $1.28^{* * *}$ & NI & .01 & $\mathrm{CO}$ & .31 & CL & $1.37^{* * *}$ & AR & $1.56^{* * *}$ & MX & $.67 *$ \\
\hline & NI & ES & $1.26^{* * *}$ & SV & -.01 & $\mathrm{CO}$ & .29 & CL & $1.35^{* * *}$ & $\mathrm{AR}$ & $1.55^{* * *}$ & MX & .66 \\
\hline & $\mathrm{CO}$ & ES & $.97 * * *$ & SV & -.31 & NI & -.29 & $\mathrm{CL}$ & $1.06^{* * *}$ & $\mathrm{AR}$ & $1.26^{* * *}$ & MX & .37 \\
\hline & CL & ES & -.09 & SV & $-1.37 * * *$ & NI & $-1.35^{* * *}$ & $\mathrm{CO}$ & $-1.06 * * *$ & $\mathrm{AR}$ & .19 & MX & -.70 \\
\hline & AR & ES & -.28 & SV & $-1.56^{* * *}$ & NI & $-1.55^{* * *}$ & $\mathrm{CO}$ & $-1.26^{* * *}$ & CL & -.19 & MX & $-.89 * * *$ \\
\hline & MX & ES & $.61^{* *}$ & SV & $-.67 *$ & NI & -.66 & $\mathrm{CO}$ & -.37 & CL & .70 & $\mathrm{AR}$ & $.89 * * *$ \\
\hline \multirow{8}{*}{ 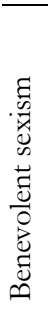 } & \multicolumn{13}{|c|}{ Total sample } \\
\hline & ES & SV & $-2.04 * * *$ & $\mathrm{NI}$ & $-2.44 * * *$ & $\mathrm{CO}$ & $-.41 * * *$ & CL & -.09 & AR & -.14 & MX & $-.47 * * *$ \\
\hline & SV & ES & $2.04 * * *$ & NI & $-.40^{*}$ & $\mathrm{CO}$ & $1.63^{* * *}$ & CL & $1.95^{* * *}$ & AR & $1.90^{* * *}$ & MX & $1.56^{* * *}$ \\
\hline & NI & ES & $2.44 * * *$ & SV & $.40^{*}$ & $\mathrm{CO}$ & $2.03^{* * *}$ & CL & $2.34 * * *$ & AR & $2.30^{* * *}$ & MX & $1.96^{* * *}$ \\
\hline & $\mathrm{CO}$ & ES & $.41 * * *$ & SV & $-1.63^{* * *}$ & NI & $-2.03 * * *$ & CL & $.32 *$ & AR & $.27 * *$ & MX & -.06 \\
\hline & CL & ES & .09 & SV & $-1.95^{* * *}$ & $\mathrm{NI}$ & $-2.34 * * *$ & $\mathrm{CO}$ & $-.32 *$ & $\mathrm{AR}$ & -.04 & MX & $-.38 *$ \\
\hline & AR & ES & .14 & SV & $-1.90 * * *$ & NI & $-2.30 * * *$ & $\mathrm{CO}$ & $-.27 * *$ & CL & .04 & MX & $-.34 * * *$ \\
\hline & MX & ES & $.47^{* * *}$ & SV & $-1.56^{* * *}$ & NI & $-1.96^{* * *}$ & $\mathrm{CO}$ & .06 & CL & $.38^{*}$ & $\mathrm{AR}$ & $.34 * * *$ \\
\hline \multicolumn{14}{|c|}{ Sample of women } \\
\hline \multirow{7}{*}{ 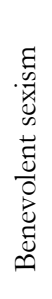 } & ES & SV & $-2.04 * * *$ & NI & $-2.50 * * *$ & $\mathrm{CO}$ & $-.41 * * *$ & CL & -.07 & AR & -.14 & MX & $-.47 * * *$ \\
\hline & SV & ES & $2.04 * * *$ & NI & -.46 & $\mathrm{CO}$ & $1.63^{* * *}$ & CL & $1.97^{* * *}$ & AR & $1.90^{* * *}$ & MX & $1.57^{* * *}$ \\
\hline & $\mathrm{NI}$ & ES & $2.50^{* * *}$ & SV & .46 & $\mathrm{CO}$ & $2.09 * * *$ & CL & $2.43^{* * *}$ & $\mathrm{AR}$ & $2.36^{* * *}$ & MX & $2.03^{* * *}$ \\
\hline & $\mathrm{CO}$ & ES & $.41 * * *$ & SV & $-1.63^{* * *}$ & NI & $-2.09 * * *$ & CL & .34 & AR & $.27 * *$ & MX & -.06 \\
\hline & CL & ES & .07 & SV & $-1.97 * * *$ & NI & $-2.43 * * *$ & $\mathrm{CO}$ & -.34 & AR & -.07 & MX & -.40 \\
\hline & $\mathrm{AR}$ & ES & .14 & SV & $-1.90 * * *$ & NI & $-2.36 * * *$ & $\mathrm{CO}$ & $-.27 * *$ & CL & .07 & MX & $-.33 * *$ \\
\hline & MX & ES & $.47 * * *$ & SV & $-1.57 * * *$ & NI & $-2.03 * * *$ & $\mathrm{CO}$ & .06 & CL & .40 & $\mathrm{AR}$ & $.33^{* *}$ \\
\hline
\end{tabular}




\begin{tabular}{|c|c|c|c|c|c|c|c|c|c|c|c|c|c|}
\hline & $\begin{array}{c}\text { Country } \\
\text { (I) }\end{array}$ & $\begin{array}{c}\text { Country } \\
\left(J_{1}\right)\end{array}$ & $\begin{array}{c}\text { Mean } \\
\text { difference } \\
\left(\mathrm{I}-\mathrm{J}_{1}\right)\end{array}$ & $\begin{array}{c}\text { Country } \\
\left(J_{2}\right)\end{array}$ & $\begin{array}{c}\text { Mean } \\
\text { difference } \\
\left(\mathrm{I}-\mathrm{J}_{2}\right)\end{array}$ & $\begin{array}{c}\text { Country } \\
\left(\mathrm{J}_{3}\right)\end{array}$ & $\begin{array}{c}\text { Mean } \\
\text { difference } \\
\left(\mathrm{I}-\mathrm{J}_{3}\right)\end{array}$ & $\begin{array}{c}\text { Country } \\
\left(\mathrm{J}_{4}\right)\end{array}$ & $\begin{array}{c}\text { Mean } \\
\text { difference } \\
\left(\mathrm{I}-\mathrm{J}_{4}\right)\end{array}$ & $\begin{array}{c}\text { Country } \\
\left(\mathrm{J}_{5}\right)\end{array}$ & $\begin{array}{c}\text { Mean } \\
\text { difference } \\
\left(\mathrm{I}-\mathrm{J}_{5}\right)\end{array}$ & $\begin{array}{c}\text { Country } \\
\left(J_{6}\right)\end{array}$ & $\begin{array}{c}\text { Mean } \\
\text { difference } \\
\left(\mathrm{I}-\mathrm{J}_{6}\right)\end{array}$ \\
\hline \multirow{7}{*}{ 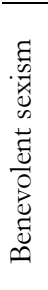 } & ES & SV & $-1.81 * * *$ & NI & $-2.11 * * *$ & $\mathrm{CO}$ & -.26 & $\mathrm{CL}$ & .10 & AR & -.14 & MX & -.38 \\
\hline & SV & ES & $1.81^{* * *}$ & NI & -.30 & $\mathrm{CO}$ & $1.55^{* * *}$ & CL & $1.91^{* * *}$ & $\mathrm{AR}$ & $1.68^{* * *}$ & MX & $1.43^{* * *}$ \\
\hline & NI & ES & $2.11^{* * *}$ & SV & .30 & $\mathrm{CO}$ & $1.86^{* * *}$ & CL & $2.21 * * *$ & $\mathrm{AR}$ & $1.98^{* * *}$ & MX & $1.73^{* * *}$ \\
\hline & $\mathrm{CO}$ & ES & .26 & SV & $-1.55^{* * *}$ & NI & $-1.86^{* * *}$ & CL & .36 & $\mathrm{AR}$ & .12 & MX & .13 \\
\hline & CL & ES & -.10 & SV & $-1.91 * * *$ & NI & $-2.21 * * *$ & $\mathrm{CO}$ & -.36 & $\mathrm{AR}$ & -.23 & MX & -.48 \\
\hline & AR & ES & .14 & SV & $-1.68^{* * *}$ & NI & $-1.98^{* * *}$ & $\mathrm{CO}$ & -.12 & $\mathrm{CL}$ & .23 & MX & -.25 \\
\hline & MX & ES & .38 & SV & $-1.43^{* * *}$ & NI & $-1.73^{* * *}$ & $\mathrm{CO}$ & .13 & CL & .48 & AR & .25 \\
\hline
\end{tabular}

Note: $\mathrm{ES}=$ Spain; SV = El Salvador; NI = Nicaragua; CO = Colombia; CL = Chile; AR = Argentina; MX $=$ Mexico; $* p \leq .05 ; * * p \leq .01 ; * * * p \leq .001$.

\section{Model of classification according to sex and country}

The classification trees were analysed using the Chisquare Automatic Interaction Detector method (CHAID). The dependent variables were the scores in the hostile sexism and benevolent sexism, while the independent variables were sex and country. Scores in sexism were divided into two groups, according to the degree of sexism: low degree (scores $<2.5)$ and medium-high degree (scores $\geq 2.5$ ). The significance degree for the division into nodes and for the union of categories was .05 .

On the one hand, the results of the hostile sexism model provided a risk estimate of $.172(\mathrm{SE}=.007)$ and correctly classify $82.8 \%$ of trainee teachers. The classification allowed to make several conclusions: a) $8.6 \%$ of trainee teachers in Spain, $45.3 \%$ in El Salvador and Nicaragua, $31.2 \%$ in Colombia, $11.6 \%$ in Argentina and Chile, and 24.3\% in Mexico showed medium-high degree of hostile sexism $\left(\chi^{2}=307.58\right.$, $p<.001$ ); b) $23.3 \%$ of men in Spain, compared to $5.2 \%$ of women, showed medium-high degree of sexism $\left(\chi^{2}=74.66\right.$, $p<.001)$; c) $62.6 \%$ of men in El Salvador and Nicaragua, compared to $34.7 \%$ of women, showed medium-high degree of hostile sexism $\left(\chi^{2}=25.39, p<.001\right)$; d) $54.8 \%$ of men in Colombia, compared to $21.8 \%$ of women, showed mediumhigh degree of hostile sexism $\left(\chi^{2}=45.77, p<.001\right)$; e) $19.4 \%$ of men in Argentina and Chile, compared to $9.5 \%$ of women, showed medium-high degree of hostile sexism $\left(\chi^{2}=\right.$ $9.24, p<.01)$; and f) $39.7 \%$ of men in Mexico, compared to $19.5 \%$ of women, showed medium-high degree of hostile $\operatorname{sexism}\left(\chi^{2}=10.67, p<.001\right)$.

On the other hand, the benevolent sexism model offered a risk estimate of $.140(S E=.007)$ and correctly classified $86 \%$ of the trainee teachers. The main findings were as follows: a) 10\% of trainee teachers in Spain and Chile, 69.9\% in El Salvador, 15.4\% in Argentina, Colombia and Mexico, and $84.4 \%$ in Nicaragua showed medium-high degree of benevolent sexism $\left(\chi^{2}=759.95, p<.001\right)$; b) $18.9 \%$ of men in Spain and Chile, compared to $7.7 \%$ of women, showed medium-high degree of benevolent sexism $\left(\chi^{2}=28.69, p<\right.$ $.001)$; c) $21.6 \%$ of men in Argentina, Colombia and Mexico, compared to $13.5 \%$ of women, showed medium-high degree of benevolent sexism $\left(\chi^{2}=10.66, p<.001\right)$; and $\left.d\right)$ gender differences are not significant in El Salvador $(70 \%$ of men and $69.8 \%$ of women showed medium-high degree; $\chi^{2}=$ $.001, p=.972)$ and in Nicaragua (88.2\% of men and $82.1 \%$ of women showed medium-high degree; $\chi^{2}=.897, p=$ $.334)$.

\section{Relationship between sexism with GII and HDI}

The relationship between ambivalent sexism and human development should be negative because they are opposite indicators. However, there should be a positive association between sexist attitudes and gender inequality because both the ASI and the GII measure issues related to inequality between men and women, albeit differently.

On the one hand, the research analysed the correlations between national mean scores for sexism and national coefficients for the GII and HDI. Although the sample has only seven countries, the results showed a trend of positive correlations between the GII with hostile sexism $(r=.78, p<.05$; $r($ Rho $)=.83, p<.05)$ and with benevolent sexism $(r=.63, p$ $>.05 ; r(\mathrm{Rho})=.82, p<.05)$, and a trend of negative correlations between HDI with hostile sexism $(r=-.97, p<.01$; $r$ (Rho) $=-.96, p<.01)$ and with benevolent sexism $(r=-.93$, $p<.01 ; r(\mathrm{Rho})=-.96, p<.01)$. On the other hand, correlations between the levels of sexism of the participants and the national values of GII and HDI were analysed. Hostile sexism scores were associated with both GII $(r=.35, p<.01$; $r(\mathrm{Rho})=.36, p<.01)$ and HDI $(r=-.41, p<.01 ; r$ (Rho $)=-$ $.40, p<.01)$. Scores in benevolent sexism were also positively related to the GII $(r=.34, p<.01 ; r(\mathrm{Rho})=.33, p<.01)$ and negatively to the HDI $(r=-.51, p<.01 ; r$ (Rho) $=-.40, p$ $<.01)$. In general, these findings provided evidence that the more gender inequality and the less human development there is in a country, the higher the levels of hostile and benevolent sexism of its trainee teachers are.

\section{Discussion}

Through socialisation, girls and boys learn and internalise the social roles, cultural values and behavioural norms of their surroundings (Bonilla-Algovia \& Rivas-Rivero, 2018; Rebollo et al., 2011a). The education system is one of principal spaces for socialisation and as such, plays a central role in achieving a just and egalitarian society (Azorín, 2017; Fabes 
et al., 2018; Pinedo et al., 2018; Sáez-Rosenkranz et al., 2019). Schools and teachers should thus be major forces for social change rather than passive spectators (Bonilla-Algovia \& Rivas-Rivero, 2019; Carretero \& Nolasco, 2019; Cordón et al., 2019; Gray \& Leith, 2004; Gullberg et al., 2018; Mai \& Brundrett, 2019; Rebollo et al., 2011b; Sáenz del Castillo et al., 2019). It is therefore necessary to pay attention to those elements, such as sexist ideology, that can form part of the hidden curriculum (Maceira, 2005) and legitimise structural gender inequality (Brandt, 2011; Glick et al., 2000; Taşdemir \& Sakall1-Uğurlu, 2010). This study analysed acceptance of ambivalent sexist attitudes in a sample of trainee teachers in Spain and Latin America.

The results showed that sexist attitudes exist to varying degrees in all the countries, which shows that trainee teachers are not free of gender biases and stereotyped beliefs (Carretero \& Nolasco, 2019; Cordón et al., 2019). Just as other studies have found that sexism still takes part of the discourses and practices of in-service teachers (Díaz \& Anguita, 2017; Sales-Oliveira et al., 2016), research confirms that sexism is also present in future teachers, who will educate the new generations. Additionally, a qualitative study of trainee teachers found that these often encounter difficulties in detecting the existence of covert gender inequalities (Pinedo et al., 2018). The results pointed in the same direction, suggesting that new forms of sexism might be more difficult to identify than old forms of sexism because they are less explicit, which poses a problem as regards the reproduction of gender inequality in the education system. With legislation that supports formal equality between men and women in most societies today, sexism has not disappeared, but has become subtler (Bonilla-Algovia \& Rivas-Rivero, 2020). With the aim of changing schools into places of social transformation, it is necessary for teachers to be able to detect explicit and implicit gender stereotypes.

Ambivalent sexism is based on the coexistence of two types of attitude that imply subjectively opposite evaluations of women (Glick \& Fiske, 1996, 2011; Rodríguez et al., 2009). Both hostile and benevolent sexism alike are based on a stereotypical view of women, but whereas hostile sexism consists of subjectively negative attitudes, benevolent sexism consists of subjectively positive attitudes. The first one reinforces male power by punishing women who challenge it, while the second one reinforces that power because it rewards women who embrace restrictive and subordinate gender roles (Glick et al., 2000; Lee et al., 2010a). In other words, although one emphasises punishment and another emphasises reward, these two types of sexism are mutually reinforcing and work in tandem towards a common goal: to perpetuate gender hierarchy and legitimise power relations between men and women (Bonilla-Algovia \& Rivas-Rivero, 2020; Glick \& Fiske, 2011; Lee et al., 2010b). This could explain the gender differences obtained in the study: men had significantly higher scores for ambivalent sexism than women in all countries.
A study conducted with a sample of future teachers found that levels of hostile sexism were significantly higher in men than in women (Carretero \& Nolasco, 2019). Likewise, a study with a sample of in-service teachers showed that women presented fewer hostile attitudes than men (Sales-Oliveira et al., 2016). The results pointed in the same direction. Male trainee teachers had significantly higher hostile sexism scores than female trainee teachers in Spain, El Salvador, Nicaragua, Colombia, Chile and Mexico. Women also scored lower than men in Argentina, but the difference in means was not significant. Different studies carried out with samples of non-teachers obtained similar results. Thus, according to previous studies conducted in Spanish-speaking countries (Boira et al., 2017; Fernández et al., 2017; León \& Aizpurúa, 2020) and in non-Spanish-speaking countries (Chen et al., 2009; Glick \& Fiske, 1996; Taşdemir \& Sakall-Ugurlu, 2010), the findings seem to confirm that men present greater acceptance of hostile sexist attitudes than women.

The cross-cultural studies of Glick et al. (2000, 2004) reported that in every nation men scored significantly higher than women in hostile sexism. However, in most countries the mean differences in benevolent sexism tended to decrease, disappear or to be reverted. Similarly, the results of this study showed that, although men tended to score higher than women in both forms of sexism, gender differences were smaller in benevolent sexism than in hostile sexism in all countries except Argentina. Female trainee teachers accepted benevolent sexism less than their male counterparts in all countries, but differences between sexes were not significant in El Salvador, Nicaragua and Chile.

Not only do these findings concur with previous crosscultural investigations, but also with the Theory of Ambivalent Sexism (Glick \& Fiske, 1996, 2011). Men, as the dominant group in patriarchal hierarchy, in comparison to women, would place themselves more in favour of hostile sexism because this ideology serves to justify their gender status quo and to maintain their position of greater social power, at the same time as supporting benevolent sexism can serve them to legitimize and compensate for hostile attitudes. Glick et al. $(2000,2004)$ found that in countries where men had high degree of hostile sexism, women were more likely to endorse benevolent sexism as a self-defence strategy. In this study, as reported by the comparison of means and the classification tree, women from countries where men were most hostile sexist (Nicaragua and El Salvador) accepted benevolent sexism more than women from other countries, and almost as much as men from their own country. Consequently, when there is a high degree of sexism in a culture, women may be forced to embrace benevolent sexism in order to ward hostility from men off (Glick et al., 2000). However, far from being liberating, benevolent ideology strengthens patriarchal system, since it praises female roles that do not pose a threat to men and reduces women's resistance to male domination (Glick \& Fiske, 1996, 2011; Lee et al., 2010b). 
Consistent with other cross-cultural studies (Brandt, 2011; Napier et al., 2010), it was found that acceptance of the ambivalent sexism varied by country. In line with the study hypotheses, levels of sexism were significantly different among countries, and these differences in means for hostile and benevolent sexism were related to gender inequality and human development. Moya et al. (2002) found that the more human development existed in a nation, the lower the levels of hostile and benevolent sexism are. Glick et al. (2000, 2004) found that national means for hostile and benevolent sexism tend to correlate with national gender inequality indices. In agreement with previous studies, it was found that as gender inequality increased and human development decreased, levels for hostile and benevolent sexism rose.

In another cross-cultural study, Brandt (2011) found that sexism is not only related to the gender status quo but also predicts it and can generate gender inequalities within societies. Thus, basing on this, the relationship observed between sexism, which measures subjective inequality, and the GII, which measures objective inequality, suggests that structural inequalities are perpetuated by a sexist belief system that endows them with ideological legitimacy. In other words, material gender inequalities (GII) would be related to and derive from ideological gender inequality (sexism). Consequently, if the main aim of any democratic country is to eliminate structural inequalities between women and men, it is essential to act on the ideologies that legitimise and produce them. Unless we act on the symbolic order (Powell \& Sang, 2015), the structure of patriarchal domination and gender inequalities in standards of living will persist.

Although the present study provides new information about acceptance of ambivalent sexism by trainee teachers in Spain and Latin America, it also presents some limitations that may have influenced the results obtained. The samples from the various countries analysed were not representative because people who met the inclusion criteria were selected. The main objective was to obtain samples of future teachers. The sample size varied across countries; however, it was guaranteed that the samples ware greater than 100 in all countries. This limitation may affect comparisons of means among countries but does not affect comparisons between men and women within countries. A lower percentage of

\section{References}

Azorín, C.M. (2017). Actitudes hacia la igualdad de género en una muestra de estudiantes de Murcia [Attitudes towards gender equality in a sample of students from Murcia]. Revista Complutense de Educación, 28(1), 45-60. https://doi.org/10.5209/rev RCED.2017.v28.n1.48715

Biemmi, I. (2015). Gender in schools and culture: taking stock of education in Italy. Gender and Education, 27(7), 812-827. https://doi.org/10.1080/09540253.2015.1103841

Boira, S., Chilet-Rosell, E., Jaramillo-Quiroz, S., \& Reinoso, J. (2017). Sexismo, pensamientos distorsionados y violencia en las relaciones de pareja en estudiantes universitarios de Ecuador de áreas relacionadas con el bienestar y la salud [Sexism, distorted thoughts and violence in dating relationships in Ecuadorian university students from areas related to men than women participated, but this is a common problem in education degrees that can be attributed to the sexual division of labour in patriarchal societies (Bonilla-Algovia \& Rivas Rivero, 2020). Future studies should take into account these limitations and continue investigating the acceptance of sexist attitudes in educational contexts, exploring new areas of research to analyse the relationship between sexism and other sociodemographic variables (e.g. age, religion, political conservatism) and sociocultural constructs (e.g. romantic myths, gender stereotypes and roles, beliefs about violence against women). Despite these limitations, these results alert that sexism is present in trainee teachers, regardless of the cultural background they belong to.

\section{Conclusions}

The results show that hostile and benevolent sexism coexist in future teachers (especially in men) and that their acceptance is related to gender inequality and human development. Even when these are unconscious, the attitudes and beliefs of teaching staff can influence teaching practice since they affect assessments of society that drive behaviour and decision-making. Educational transformation will therefore require changes in attitudes towards gender equality in the teaching profession. Tackling sexism in class is beneficial for teachers and students alike; however, the difficulties teachers encounter in detecting new forms of sexism may limit their ability to address these in class. This suggests the need to incorporate a gender and feminist perspective in initial and inservice teacher training. Such training should include material that helps teachers to detect gender inequalities and provides them with the resources to act accordingly. Inequalities between men and women are a structural problem that requires changes in the different social structures. In conclusion, although educational institutions cannot eradicate all inequalities, they play a leading role in counteracting them and producing socio-cultural changes. Building more equitable and just societies cannot be achieved without the support of education system and teachers.

Acknowledgments.- This work has been carried out with the support of FPU Contract of the University of Alcalá. well-being and health]. Universitas Psychologica, 16(4), 1-12. https://doi.org/10.11144/Javeriana.upsy16-4.spdv

Bonilla-Algovia, E., \& Rivas-Rivero, E. (2018). Mitos del amor romántico en una muestra de futuros y futuras docents [Myths of romantic love in a sample of future and future teachers]. Revista de Estudios e Investigación en Psicología y Educación, 5(2), 113-117. https://doi.org/10.17979/reipe.2018.5.2.3624

Bonilla-Algovia, E., \& Rivas-Rivero, E. (2019). Creencias distorsionadas sobre la violencia contra las mujeres en docentes en formación de $\mathrm{Co}^{-}$ lombia [Distorted beliefs about violence against women in teacher training in Colombia]. Revista Colombiana de Educación, 1(77), 1-20. https://doi.org/10.17227/rce.num77-9571 
Bonilla-Algovia, E. \& Rivas-Rivero, E. (2020). Validez de la versión reducida de la Escala de Sexismo Ambivalente en El Salvador y México [Validity of the reduced version of the Ambivalent Sexism Scale in El Salvador and Mexico]. Revista Mexicana de Psicología, 37(2), 92-103.

Brandt, MJ. (2011). Sexism and Gender Inequality Across 57 Societies. Psychological Science, 22(11), 1413-1418. https://doi.org/10.1177\%2F0956797611420445

Brundrett, M., \& Dung, M.T.T. (2018). The challenge of ensuring gender equality in Vietnamese and English high schools: espoused and real commitments. International Journal of Comparative Education and Development, 20(1), 2-15. https://doi.org/10.1108/IJCED-09-2017-0025

Carretero, R., \& Nolasco, A. (2019). Sexismo y formación inicial del profesorado. Educar, 5(1), 293-310. https://doi.org/10.5565/rev/educar.903

Chen, Z., Fiske, S.T., \& Lee, T.L. (2009). Ambivalent Sexism and PowerRelated Gender-role Ideology in Marriage. Sex Roles, 60, 765-778. https://doi.org/10.1007/s11199-009-9585-9

Cordón, S., Gutiérrez-Esteban, P., \& Cubo, S. (2019). Development of sexist attitudes in primary school teachers during their initial teacher training. Women's Studies International Forum, 72, 32-39. https://doi.org/10.1016/j.wsif.2018.11.005

Cushman, P. (2012). 'You're not a teacher, you're a man': the need for a greater focus on gender studies in teacher education. International Journal of Inclusive Education, 16(8), 775-790. https://doi.org/10.1080/13603116.2010.516774

Díaz, S., \& Anguita, R. (2017). Estereotipos del profesorado en torno al género y a la orientación sexual [Teacher stereotypes around gender and sexual orientation]. Revista Electrónica Interuniversitaria de Formación del Profesorado, 20(1), 219-232. https://doi.org/10.6018/reifop/20.1.228961

Fabes, R.A., Martin, C. L., Hanish, L.D., \& DeLay, D. (2018). Gender integration in coeducational classrooms: Advancing educational research and practice. School Psychology Quarterly, 33(2), 182190. https://doi.org/10.1037/spq0000266

Fernández, S., Arias, W.L., \& Alvarado, M. (2017). La escala de sexismo ambivalente en estudiantes de dos universidades de Arequipa [The scale of ambivalent sexism in students from two Arequipa universities]. Avances en Psicología, 25(1), 85-96. https://doi.org/10.33539/avpsicol2017v25n1.138

Glick, P., \& Fiske, S.T. (1996). The Ambivalent Sexism Inventory: Differentiating Hostile and Benevolent Sexism. Journal of Personality and Social Psychology, 70(3), 491-512. http:// doi.org/10.1037/0022-3514.70.3.491

Glick, P., \& Fiske, S.T. (2011). Ambivalent Sexism Revisited. Psychology of Women Quarterly, 35(3), 530-535. https://doi.org/10.1177/0361684311414832

Glick, P., Fiske, S.T., Mladinic, A., Saiz, J.L., Abrams, D., Masser, B., ... \& López, W.L. (2000). Beyond prejudice as simple antipathy: hostile and benevolent sexism across cultures. Journal of Personality and Social Psychology, 79(5), 763-775. http://doi.org/10.1037/0022-3514.79.5.763

Glick, P., Lameiras, M., Fiske, S.T., Eckes, T., Masser, B., Volpato, C., ... \& Wells, R. (2004). Bad but Bold: Ambivalent Attitudes Toward Men Predict Gender Inequality in 16 Nations. Journal of Personality and Social Psychology, 86(5), 713-728. https://doi.org/10.1037/0022-3514.86.5.713

Gonçalves, G., Orgambídez-Ramos, A., Giger, J.C., Santos, J., \& Gomes, A. (2015). Validity evidence of the Portuguese adaptation of the Ambivalent Sexism Inventory. International Journal of Social Psychology, 30(1), 152181. https://doi.org/10.1080/02134748.2014.991518

Gray, C., \& Leith, H. (2004). Perpetuating gender stereotypes in the classroom: a teacher perspective. Educational Studies, 30(1), 3-17. https://doi.org/10.1080/0305569032000159705

Gullberg, A., Andersson, K., Danielsson, A., Scantlebury, K., \& Hussénius, A. (2018). Pre-Service Teachers' Views of the Child-Reproducing or Challenging Gender Stereotypes in Science in Preschool. Research in Science Education, 48(4), 691-715. https://doi.org/10.1007/s11165-016$\underline{9593-Z}$

Lee, T.L., Fiske, S.T., Glick, P., \& Chen, Z. (2010a). Ambivalent Sexism in Close Relationships: (Hostile) Power and (Benevolent) Romance Shape Relationship Ideals. Sex Roles, 62(7-8), 583-601. https://doi.org/10.1007/s11199-010-9770-x

Lee, T.L., Fiske, S.T., \& Glick, P. (2010b). Next gen ambivalent sexism: Converging correlates, causality in context, and converse causality, an introduction to the special issue. Sex Roles, 62(7-8), 395-404. https://doi.org/10.1007/s11199-010-9747-9

León, C.M. \& Aizpurúa, E. (2020). ¿Persisten las actitudes sexistas en los estudiantes universitarios? Un análisis de su prevalencia, predictores y diferencias de género [Do sexist attitudes persist in college students? An analysis of its prevalence, predictors and gender differences]. Educación XX1, 23(1), 275-296. https://doi.org/10.5944/educxx1.23629

López-Sáez, M.Á., García-Dauder, D., \& Montero, I. (2019). El sexismo como constructo en psicología: una revisión de teorías e instrumentos [Sexism as a construct in psychology: a review of theories and instruments]. Quaderns de Psicologia, 21(3), e1523. https://doi.org/10.5565/rev/qpsicologia.1523

Maceira, L. (2005). Investigación del currículo oculto en la educación superior: alternativa para superar el sexismo en la escuela [Investigation of the hidden curriculum in higher education: alternative to overcome sexism in school]. La Ventana, Revista de Estudios de Género, 3(21), 187-227.

Mai, D.T.T., \& Brundrett, M. (2019). The beliefs and attitudes of teachers and school leaders on gender equality in Vietnamese primary schools: case studies of four schools. Education 3-13, International Journal of Primary, Elementary and Early Years Education. https://doi.org/10.1080/03004279.2019.1612455

Matheis, S., Keller, L.K., Kronborg, L., Schmitt, M., \& Preckel, F. (2020). Do stereotypes strike twice? Giftedness and gender stereotypes in preservice teachers' beliefs about student characteristics in Australia. AsiaPacific Journal of Teacher Education, 48(2), 213-232. https://doi.org/10.1080/1359866X.2019.1576029

Moya, M., Páez, D., Glick, P., Fernández, I., \& Poeschl, G. (2002). Sexismo, Masculinidad-Feminidad y Factores Culturales [Sexism, MasculinityFemininity and Cultural Factors]. Revista Española de Motivación y Emoción, 3, 127-142

Napier, J.L., Thorisdottir, H., \& Jost, J.T. (2010). The Joy of Sexism? A Multinational Investigation of Hostile and Benevolent Justifications for Gender Inequality and Their Relations to Subjective Well-Being. Sex Roles, 62(7-8), 405-419. https://doi.org/10.1007/s11199-009-9712-7

Pinedo, R., Arroyo, M.J., \& Berzosa, I. (2018). Género y educación: detección de situaciones de desigualdad de género en contextos educativos [Género y educación: detección de situaciones de desigualdad de género en contextos educativos]. Contextos Educativos, 21, 35-51. https://doi.org/10.18172/con.3306

Powell, A., \& Sang, K.J.C. (2015). Everyday Experiences of Sexism in Maledominated Professions: A Bourdieusian Perspective. Sociology, 49(5), 919-936. https://doi.org/10.1177/0038038515573475

Rebollo, M.Á., García, R., Piedra, J., \& Vega, L. (2011a). Diagnóstico de la cultura de género en educación: actitudes del profesorado hacia la igualdad Diagnosis of gender culture in education: teacher attitudes towards equality]. Revista de Educación, 355, 521-546. https://doi.org/104438/1988-592X-RE-2010-355-035

Rebollo, M.Á., Vega, L., \& García-Pérez, R. (2011b). El profesorado en la aplicación de planes de igualdad: conflictos y discursos en el cambio educativo [Teachers in the application of equality plans: conflicts and discourses in educational change]. Revista De Investigación Educativa, 29(2), 311-323.

Rodríguez, Y., Lameiras, M., \& Carrera, M.V. (2009). Validación de la versión reducida de las escalas ASI y AMI en una muestra de estudiantes españoles [Validation of the reduced version of the ASI and AMI scales in a sample of Spanish students]. Psicogente, 12(22), 284-295.

Sáenz del Castillo, A., Goñi, E., \& Camuñas, A. (2019). La coeducación a debate: representaciones sociales en el profesorado de Educación Infantil [Coeducation under debate: social representations in Early Childhood Education teachers]. Profesorado, Revista de Currículum y Formación del Profesorado, 23(2), 463-484. https://doi.org/10.30827/profesorado.v23i2.9726

Sáez-Rosenkranz, I., Barriga-Ubed, E. \& Bellatti, I. (2019). La coeducación como perspectiva formativa para la enseñanza de la historia en la ESO [Coeducation as a formative perspective for the teaching of history in ESO]. Revista Electrónica Interuniversitaria de Formación del Profesorado, 22(2), 17-30. https://doi.org/10.6018/reifop.22.2.370201

Sales-Oliveira, C., Villas-Boas, S., \& Las-Heras, S. (2016). Estereótipos de género e sexismo em docentes do ensino superior [Gender stereotypes and sexism in higher education teachers]. Revista Iberoamericana de Educa- 
ción Superior, $\quad 7(19)$,

https://doi.org/10.22201/iisue.20072872e.2016.19.185

Sánchez, A. (2002). El androcentrismo científico: el obstáculo para la igualdad de género en la escuela actual [Scientific androcentrism: the obstacle to gender equality in today's school]. Educar, (29), 91-102. https://doi.org/10.5565/rev/educar.331

$22-41$.
Taşdemir, N., \& Sakall-Uğurlu, N. (2010). The relationships between ambivalent sexism and religiosity among Turkish university students. Sex Roles, 62(7-8), 420-426. https://doi.org/10.1007/s11199-009-9693-6

UNDP (2019). Human Development Report 2019. Beyond income, beyond averages, beyond today: Inequalities in human development in the 21st century. New York: United Nations Development Programme. 